\author{
IRENA BIEŃKOWSKA \\ UNIWERSYTET WARSZAWSKI
}

\title{
PREVIOUSLY UNKNOWN SOURCES FOR JOHANN PHILIPP KIRNBERGER'S FLUTE SONATAS FOUND IN THE FORMER RZEWUSKI MUSIC COLLECTION FROM PODHORCE (PIDHIRTSI)*
}

\begin{abstract}
Tn a collection of instrumental compositions that I have been researching for some time, ${ }^{\mathrm{I}}$ I have come across anonymous sonatas which, on closer inspection, have proved to be works by Johann Philipp Kirnberger (I72I-83). To date, they are the first and only musical sources that indirectly confirm that outstanding theorist and composer's ten-year period of activity in the Polish-Lithuanian Commonwealth.
\end{abstract}

\section{JOHANN PHILIPP KIRNBERGER AND HIS YEARS IN THE POLISH-LITHUANIAN}

\section{COMMONWEALTH}

The first thirty years of Johann Philipp Kirnberger's life and work are very poorly researched. This period is of particular interest to Polish musicology since that pupil of the illustrious Johann Sebastian Bach was active in the Polish-Lithuanian Commonwealth at that time. ${ }^{2}$ Kirnberger is known to have been born in April I72I in Saalfeld, one of Thüringen's oldest towns. He began his music education at

* This publication has been financed by the Minister of Education and Science from the 'National Programme for the Development of Humanities 2020-2025', project no. $11 \mathrm{H} 180039$ 87, total amount financed: PLN 1,016,462.50.

1 See: Irena Bieńkowska, 'Osiemnastowieczna twórczość instrumentalna z dawnej kolekcji muzykaliów w Podhorcach' [Eighteenth-century instrumental works in the former music collection from Podhorce], Barok. Historia-Literatura-Sztuka 26 (2019) no. 1, pp. 165-184; Sonaty Francesca Marii Cattaneo oraz finali i duetto z rękopisu tarnowskiego (PL-TA 23) [Sonatas by Francesco Marii Cattaneo (1697-1758) as well as the finali and duetto from the Tarnów manuscript (PL-TA 23)], introd. and ed. Irena Bieńkowska, Warszawa 2018 (= Musica Revelata, M/1); Sei Concerti a flauto traversiere obligato z rękopisu tarnowskiego (PL-TA 49-54) [Sei Concerti a flauto traversiere obligato from the Tarnów manuscript (PL-TA 49-54)], introd. and ed. Irena Bieńkowska, Warszawa 2019 (= Musica Revelata, M/2).

2 Kirnberger's stay in the Polish-Lithuanian Commonwealth has recently been referred to by Szymon Paczkowski, 'Bach and Poland in the Eighteenth Century', Understanding Bach 10 (2015), pp. 123-137. 
home; subsequently he attended a Latin school in Coburg and probably in Gotha. Before 1738 he continued to learn the organ at Gräfenrod, and from 1738 violin and organ at Sondershausen, where he stayed till 1740 (or, as Marpurg claims, ${ }^{3}$ only until 1739). From Sondershausen he went to Leipzig, where he studied composition with Johann Sebastian Bach. Entries in Kirnberger's notebook tell us that in June $174 \mathrm{I}$ he found himself in Dresden. ${ }^{4}$ It seems reasonable to accept Max Seiffert's suggestion that the musician's stay in that city (he was barely twenty years old and looking for employment) must have played a key role in his decision to leave for the Polish-Lithuanian Commonwealth. ${ }^{5}$ First of all, while at the court of the king of Poland and elector of Saxony, Kirnberger had the opportunity to make contact with Polish magnates. Secondly, and equally importantly it seems, it was there that he met Franz Joseph Götzl (Götzel), ${ }^{6}$ a member of the Dresden court ensemble - an event Kirnberger noted in his diary under the date 9 June 174I. As flautist in the Kurfürstlich-Sächsische und Königlich-Polnische Kapelle, Götzl had replaced Johann J. Quantz (I697-I773). Götzl and Quantz had studied together with Pierre-Gabriel Buffardin for several months. ${ }^{7}$ Quantz had played in Augustus III's Polish ensemble in Warsaw for nearly six years (1718-24), and it is possible that he remembered this as a good period in his life. Indeed, thanks to the support of his Polish protectors, who included Aleksander Jakub Lubomirski (1695-1772), Quantz undertook an educational journey to Italy in 1724 . He was apparently grateful to his benefactors for this opportunity, since he took care to mention it in his autobiography. ${ }^{8}$ Notably, both Franz's father Johann Joseph (a long-serving musician in the Dresden Kapelle) and Pierre G. Buffardin had spent half a year (from early December 1735 till June 1736) at the royal court in Warsaw, helping to

3 Friedrich Wilhelm Marpurg, Historisch-kritische Beyträge zur Aufnahme der Musik, vol. 1, Berlin 1754 Joh. Jacob Schützens sel. Witwe, p. 85.

4 Kirnberger's notebook is now considered lost; we know it in fragments thanks to the publication by Max Seiffert, 'Notizen, "Aus dem Stammbuche Johann Philipp Kirnberger's", Vierteljahrsschrift für Musikwissenschaft 5 (1889) no. 2, pp. 365-371.

5 M. Seiffert, 'Notizen', pp. 366-367.

6 Franz Joseph Götzl (Götzel) (d. Dresden, 1797), a flautist who joined the Dresden court ensemble in 1741, retired in 1777. He gave performances in many European cities, including London, Paris, The Hague and Hamburg. Cf. Robert Eitner, Biographisch-Bibliographisches Quellen-Lexikon der Musiker und Musikgelehrten, Leipzig 1900-04, 10 vols., see vol. 4, p. 298; Christoph Johann Gottfried Haymann, Dresdens theils neuerlich verstorbene theils jetzt lebende Schriftsteller und Künstler wissenschaftlich classificirt nebst einem dreyfachen Register, Dresden 1809 Waltherschen Hofbuchhandlung, p. 560. Götzl left about a dozen flute sonatas and concertos listed in the RISM database. I am grateful to Wim Brabants for pointing out the incorrect date for the death of Franz J. Götzl given in RISM (1823).

7 See: Edward R. Reilly 'Pierre-Gabriel Buffardin', in: Grove Music Online, ed. Stanley Sadie, https://doi. org/10.1093/gmo/9781561592630.article.04264 (accessed 7 January 2021).

8 Johann Joachim Quantz, 'Herrn Johann Joachim Quantzens Lebenslauf von ihm selbst entworfen', in: Friedrich Wilhelm Marpurg, Historisch-kritische Beyträge zur Aufnahme der Musik, vol. 1, ch. 3, Berlin 1755 Joh. Jacob Schützens sel. Witwe, pp. 215, 222. 
establish Augustus III's newly founded music ensemble. ${ }^{9}$ One may thus suspect that it was the Dresden musicians' favourable opinion about the Polish-Lithuanian state and the possible contacts with Polish noblemen (or their representatives at the Saxon electoral court) that eventually convinced Kirnberger he should try his chances in Poland. The composer left Germany in the summer of I74I (probably in June) and reached the Commonwealth most likely in the autumn.

Information concerning Kirnberger's years in the Polish-Lithuanian Commonwealth is incomplete and comes, as in the case of the preceding years, from two sources: Marpurg's brief note and the publication by Max Seiffert, who based his knowledge on entries from Kirnberger's diary then in his possession, but now considered lost. ${ }^{\text {IO }}$ Marpurg gives us the composer's successive places of employment, extremely laconically and without dates, but listing the musician's posts. He was a harpsichordist at the courts of such magnates as Poniński, starost of Piotrków, Rzewuski, voivode of Podolia and the king's deputy pantler, and Stanisław Lubomirski, a future voivode of Kiev, as well as Kapellmeister at the Convent of the Observant Franciscan Nuns in Lviv (Polish Lwów). ${ }^{I}$ Seiffert supplements Marpurg's data with information found in Kirnberger's diary.

The early years of the musician's time in the Commonwealth already give rise to numerous doubts. Marpurg quotes the name of Józef Poniński (d. I770), starost of Piotrków, as Kirnberger's first employer, and this information is repeated by Seiffert, who relates this fact to the places visited by the composer and listed in his notebook. Seiffert thus associates Kirnberger's post at Poniński's court with Częstochowa, and he quotes a diary entry: 'Częstochowa, I4 May I742', arguing that Częstochowa was part of the Piotrków starosty. ${ }^{12}$ Thus the musician's note is supposed to prove that he was still in Poniński's employment in the spring of 1742 . However, in 1742 Częstochowa was part of the Kraków voivodeship, starosty of

9 Alina Żórawska-Witkowska, Muzyka na polskim dworze Augusta III [Music at the Polish court of Augustus III], part 1, Lublin 2012, p. 167.

10 F.W. Marpurg, Historisch-kritische Beyträge, pp. 85-86; M. Seiffert, 'Notizen', pp. 365-371. Kirnberger's letters to Johann N. Forkel, though no doubt extremely important as a source of information about his life, contain no information about his stay in the Polish-Lithuanian Commonwealth. Cf. Johann Gottfried Heinrich Bellermann, 'Briefe von Kirnberger an Forkel', Allgemeine musikalische Zeitung 6 (1871), pp. 529-534, 550-554, 565-572, 614-618, 628-630, 645-648, 661-664, 677-678, 7 (1872), pp. 441, 457.

11 'Er fand darauf in Jahre 1741 Gelegenheit nach Pohlen zu gehen, woselbst er sich zehn Jahr aufgehalten, in welcher Zeit er zuförderst bey dem Starosten von Petrikau, Herrn Grafen von Poninsky, hernach bey dem Woywoden von Podolien, Herrn Grafen Rzewusky, itzigen Kronunterfeldherrn, drittens bey dem Fürsten Stanislaw Lubomisky zu Rufno in Volhynien, und zwar an allen diessen Höfen als Clavicembalist, und endlich bey den Klosterjungfern des Bernhardiner Ordens zu ReuschLemberg als Musikdirektor in Diensten gestanden hat'. F. W. Marpurg, Historisch-kritische Beyträge, pp. 85-86.

12 'Diese Stadt liegt im Gouvernement Petrikau, und bei dem Starosten von Petrikau, dem Grafen von Poninski, stand Kirnberger in diensten als Cembalist', M. Seiffert, 'Notizen', p. 367. 
Lelów. Seiffert's mistake was probably due to the fact that in his own times (I889) Częstochowa (then the seat of a separate starosty) lay in the Piotrków province of Russia. Hence Kirnberger's time in Częstochowa does not directly prove his association with the Poniński family in that period. ${ }^{13}$ The latter had a small manor house in Lipie, approximately $35 \mathrm{~km}$ north-west of Częstochowa. The choice of Kirnberger's first Polish protector also seems curious. Why did he enter into the service of Józef Poniński? Admittedly, Poniński was described by Franciszek Kamiński as a person 'of considerable knowledge', communicating in several languages ${ }^{14}$ but nothing is known about his possible musical interests or any court ensemble. Nor do we have any information (important in this context) about his stays at the Polish-Saxon court in Dresden. Józef’s father, Antoni Józef Poniński (c.1690-1742), may be the key to solving this puzzle. A highly regarded poet in his lifetime, author of Latin panegyrics published in Warsaw and Dresden, he was closely associated with the royal court and frequently travelled to Saxony. Though no records of either Józef Poniński or his father staying in Dresden in the summer of I74I have been found, the Polish poet's name may have been familiar to many in Dresden's artistic circles. This may have led Kirnberger to seek protection in a strange country among members of the Poniński family.

Be that as it may, in the year that followed his sojourn in Częstochowa, 1743 (for which we have diary entries from March and October), the composer arrived in Lviv, where, according to Seiffert, he became associated with the Convent of the Observant Franciscan Nuns. Seiffert does not specify whether this place of employment is his own conjecture or was mentioned in Kirnberger's diary. The following year, in May 1744, the musician notes his stay in Podhorce (now Pidhirtsi, Ukraine), then the estate of Podolian voivode Wacław Piotr Rzewuski (I706-79). Unable precisely to identify that place by its name, Seiffert does not connect Kirnberger's stay in Podhorce in that period with the name of Wacław Rzewuski. ${ }^{\text {Is }}$ Having resided and worked in the Polish-Lithuanian Commonwealth for nearly three years, Kirnberger was now quite knowledgeable about the geographic and cultural realities of the south-eastern part of the country. He thus sought employment at the court of one the most outstanding patrons of music at that time. Wacław Rzewuski not only maintained a good and sizeable ensemble, but also exhibited a keen interest in all things musical. He had a large collection of instruments (flutes and

13 It is worth noting that Józef Poniński's estates were located in the Halych and Przemyśl regions in the Ruthenian Voivodeship. See: Wojciech Szczygielski, 'Poniński Józef', in: Polski Stownik Biograficzny, ed. Emanuel Rostworowski, vol. 28, Wrocław-Kraków 1984-85, p. 536.

14 Ibid., p. 536.

15 Seiffert believes that Kirnberger may have stayed at Rzewuski's court in 1746 (he mistakenly gives the magnate's first name as Kazimierz), though he does not substantiate this claim in any way. Cf. M. Seiffert, 'Notizen', pp. 367-368. 
violins in particular), music-related volumes and theoretical writings. ${ }^{16} \mathrm{He}$ was also a keen amateur flautist. ${ }^{17}$

One and a half years later, in December 1745, a note in Kirnberger's diary confirms his stay at Równe (now Rivne, Ukraine), which belonged to Stanisław Lubomirski (I704-93), the later Kievan voivode. Równe, which was relatively close to Podhorce, also had a large music ensemble, in which Kirnberger had the opportunity to meet such interesting artists as Antoni Kossołowski (Kozłowski), ${ }^{18}$ a violinist and future member of Jan Klemens Branicki's orchestra in Białystok, also a royal musician and composer (though admittedly not very adept in that latter role).

We have no records concerning Kirnberger's whereabouts in 1746. Between June I747 and April I748, he resided, according to his diary entries, again in Lviv. ${ }^{\text {I9 }}$ In conjunction with Marpurg's listings, we should associate his stay in Lviv with the Observant Nuns' Convent of the Immaculate Conception of the Blessed Virgin Mary, where he held the post of Kapellmeister. It is now impossible to say for how long the composer worked there; the nuns' archive was lost after the dissolution of their order by Joseph II in $1782 .{ }^{20}$ Seiffert puts forward the hypothesis that Kirnberger remained in Lviv till the end of his stay in the Polish-Lithuanian Commonwealth, that is, until I75I. The next entry in his diary, dated May I75I, refers to his stay in Coburg, and in October of the same year he notes that he is residing in Gotha. This suggests that he left the Commonwealth early in I75I.

This information, although not yet confirmed by source materials from the archives of the noble families that employed the composer and those of the Observant Nuns' Convent, nevertheless indicate the German musician's considerable mobility during the first six years of his work in the Polish-Lithuanian Commonwealth. He did not stay long with any of those aristocratic patrons (only about one and a half years in each place), and eventually settled as a convent musician.

16 Benjamin Vogel, 'Do dziejów tradycji muzycznych zamku w Podhorcach' [Towards the history of music traditions at Podhorce Castle], Polski Rocznik Muzykologiczny 13 (2015), pp. 99-124.

17 See: I. Bieńkowska, 'Osiemnastowieczna twórczość instrumentalna', pp. 170-173.

18 F.W. Marpurg, Legende einiger Musikheiligen, Breslau 1786 Cölln am Rhein bey P. Hammern, p. 63. See also: A. Żórawska-Witkowska, Muzyka na polskim dworze, pp. 181-182.

19 This and the earlier stay in Lviv have frequently been confused in the subject literature with Kirnberger's presence in the abbey of the Benedictine Nuns (not the convent of the Observant Nunst). Cf. Jerzy Erdman, 'Kirnberger, Johann Philipp', in: Encyklopedia Muzyczna PWM [PWM Music encyclopaedia], ed. Elżbieta Dziębowska, vol. 5, Kraków 1997, p. 89; Howard Serwer, 'Kirnberger, [Kernberg], Johann Philipp', in: Grove Music Online, ed. Stanley Sadie, https://doi.org/10.1093/gmo/9781561592630.article.15061 (accessed 7 January 2021).

20 Maria Borkowska, Leksykon zakonnic polskich epoki przedrozbiorowej [Lexicon of Polish nuns in pre-partition times], vol. 3, Wielkie Księstwo Litewskie i Ziemie Ruskie Korony Polskiej [The Grand Duchy of Lithuania and the Ruthenian lands of the Polish Crown], Warszawa 2008, p. 261. Remnants of the Observant Nuns' account books for 1726-29 (MS 2962/II) held in the National Ossoliński Institute in Wrocław include entries concerning the purchase of instruments, payments of fees for the nuns' singing and instrument training, remuneration for an unnamed composer, for writing concertos, Vespers, etc. 
THE PODHORCE MANUSCRIPTS (TARNÓW MUNICIPAL LIBRARY, MSS 44 AND 45)

Our knowledge of Kirnberger's activity in the Commonwealth has so far been limited, as mentioned above, to entries from his lost diary and Marpurg's very brief note. These sources can now be supplemented with two music manuscripts once belonging to the music collection from Podhorce, which contain two of Kirnberger's flute sonatas and offer testimony of his music's reception at that court.

The Tarnów Municipal Library (Department of Early Prints and Nineteenth-Century Books) holds a collection of eighteenth-century manuscripts from Podhorce which comprise instrumental music, mostly for flute or violin with basso continuo. ${ }^{21}$ The sonatas that are the subject of this paper can be found in two twin manuscripts shelf-marked PL-TAb 44 and 45 . They are of identical format $(220 \times 310 \mathrm{~mm})$, without title pages, indication of ownership or author's notes. On the basis of the watermark, these sources can be dated approximately to the 1750 or oarly 1760 s. $^{22}$

The two manuscripts contain a total of seventeen compositions: fifteen sonatas for flute and b.c. as well as two sonatas for two flutes (see Table I). Of the eleven sonatas found in PL-TAb 44 and ten in PL-TAb 45, four are copies of the same works. These are sonatas by Johann Philipp Kirnberger written out twice, marked in the manuscripts respectively with the numbers seven and eight, and two duetti scored for flute (the Flauto primo part appears in MS 44, the Flauto secundo part in MS 45).

One of the reasons for the double entries may have been the unusual keys of $F$ sharp major and E flat minor (marked in the manuscripts as D sharp minor) in which these compositions are written, and which could pose some difficulty for performers.

Table I. Tarnów Municipal Library, MSS 44 and 45

\begin{tabular}{|l|l|l|l|l|l|l|l|}
\hline $\begin{array}{l}\text { PL-TAb 44, } \\
\text { title on source }\end{array}$ & Metre & Scoring & Concordances & $\begin{array}{l}\text { PL-TAb 45, } \\
\text { title on source }\end{array}$ & Metre & Scoring & Concordances \\
\hline $\begin{array}{l}\text { Sonata Prima } \\
\text { [in F] }\end{array}$ & & fl, b.c. & & $\begin{array}{l}\text { Sonata Prima } \\
\text { [in C] } \\
\text { [Friedrich } \\
\text { Hartmann } \\
\text { / Christian } \\
\text { Ernst, Sonata } \\
\text { in C] }\end{array}$ & & fl, b.c. & $\begin{array}{l}\text { DK-Kk mu } \\
6210.1830\end{array}$ \\
& & & & & & & \\
& & & & & & \\
\hline
\end{tabular}

21 Concerning this collection, see I. Bieńkowska, 'Osiemnastowieczna twórczość instrumentalna', pp. 166-170.

22 Ibid., pp. 166, 170. Sei Concerti a flauto traversiere obligato, p. 11. 


\begin{tabular}{|c|c|c|c|c|c|c|c|}
\hline $\begin{array}{l}\text { Adagio } \\
\text { [incomplete] }\end{array}$ & $\mathrm{C}$ & & & $\begin{array}{l}\text { Largo } \\
\text { [incomplete] }\end{array}$ & $3 / 4$ & & \\
\hline [missing part] & - & & & Allegro & $\phi$ & & \\
\hline $\begin{array}{l}\text { [no agogic } \\
\text { designation of } \\
\text { the movt] }\end{array}$ & $3 / 4$ & & & Cantabile & $3 / 8$ & & \\
\hline $\begin{array}{l}\text { Sonata 2da } \\
{[\text { in } g]}\end{array}$ & & fl, b.c. & & $\begin{array}{l}\text { Sonata 2da } \\
{[\text { in G] }}\end{array}$ & & fl, b.c. & \\
\hline Adagio & $12 / 8$ & & $\begin{array}{l}\text { movt II } \\
\text { Sonata quinta, } \\
\text { PL-TAb } 23\end{array}$ & Grave & $\phi$ & & \\
\hline Allegro & $\mathrm{C}$ & & $\begin{array}{l}\text { movt I Sonata } \\
\text { quinta, PL- } \\
\text { TAb } 23\end{array}$ & Allegro & $3 / 4$ & & \\
\hline Allegro & $2 / 4$ & & $\begin{array}{l}\text { movt III } \\
\text { Sonata quinta, } \\
\text { PL-TAb } 23\end{array}$ & Allegro & $3 / 8$ & & \\
\hline $\begin{array}{l}\text { Sonata 3tia } \\
\text { [in g] } \\
\text { [Frederick } \\
\text { the Great, } \\
\text { Sonata Flauto } \\
\text { Traversiero } \\
\text { solo, G minor] }\end{array}$ & & fl, b.c. & $\begin{array}{l}\text { D-KA Mus. } \\
\text { Hs. 151; PL- } \\
\text { TAb } 23\end{array}$ & $\begin{array}{l}\text { Sonata Terza } \\
{[\text { in G] }}\end{array}$ & & fl, b.c. & \\
\hline $\begin{array}{l}\text { Adagio } \\
\text { [incomplete] }\end{array}$ & $12 / 8$ & & $\begin{array}{l}\text { movt II } \\
\text { Sonata sesta, } \\
\text { PL-TAb } 23\end{array}$ & Adagio & $\mathrm{C}$ & & \\
\hline [incomplete] & $\mathrm{C}$ & & $\begin{array}{l}\text { movt I Sonata } \\
\text { sesta, PL-TAb } \\
23\end{array}$ & Allegro & $\mathrm{C}$ & & \\
\hline $\begin{array}{l}\text { [no agogic } \\
\text { designation of } \\
\text { the movt] }\end{array}$ & $2 / 4$ & & $\begin{array}{l}\text { movt III } \\
\text { Sonata sesta, } \\
\text { PL-TAb } 23\end{array}$ & Allegro & $\mathrm{C}$ & & \\
\hline $\begin{array}{l}\text { Sonata 4ta } \\
\text { [in c] }\end{array}$ & & fl, b.c. & & $\begin{array}{l}\text { Sonata 4ta } \\
\text { [in e] }\end{array}$ & & fl, b.c. & \\
\hline Adagio & $\mathrm{C}$ & & $\begin{array}{l}\text { movt I Sonata } \\
\text { terza, PL-TAb } \\
23\end{array}$ & Adagio & $\phi$ & & $\begin{array}{l}\text { movt I Sonata } \\
\text { seconda, } \\
\text { PL-TAb } 23\end{array}$ \\
\hline $\begin{array}{l}\text { [no agogic } \\
\text { designation } \\
\text { of the movt, } \\
\text { incomplete] }\end{array}$ & $2 / 4$ & & $\begin{array}{l}\text { movt II } \\
\text { Sonata terza, } \\
\text { PL-TAb } 23\end{array}$ & Allegro & $\mathrm{C}$ & & $\begin{array}{l}\text { movt II } \\
\text { Sonata } \\
\text { seconda, } \\
\text { PL-TAb } 23\end{array}$ \\
\hline [missing part] & - & & & Allegro & $3 / 4$ & & \\
\hline
\end{tabular}




\begin{tabular}{|c|c|c|c|c|c|c|c|}
\hline $\begin{array}{l}\text { [Sonata } \\
\text { Quinta in A] }\end{array}$ & & fl, b.c. & & $\begin{array}{l}\text { Sonata } \\
\text { Quinta [in e] }\end{array}$ & & fl, b.c. & \\
\hline [incomplete] & $\mathrm{C}$ & & & Adagio & $\mathrm{C}$ & & \\
\hline Allegro & $2 / 4$ & & & Allegro & $\mathrm{C}$ & & \\
\hline Allegro & $2 / 4$ & & & Allegro & $\mathrm{C}$ & & $\begin{array}{l}\text { movt III } \\
\text { Sonata } \\
\text { seconda, } \\
\text { PL-TAb } 23\end{array}$ \\
\hline $\begin{array}{l}\text { Sonata 6ta } \\
{[\text { in E] }}\end{array}$ & & fl, b.c. & & $\begin{array}{l}\text { Sonata Sexta } \\
{[\text { in G] }}\end{array}$ & & fl, b.c. & \\
\hline Adagio & $\phi$ & & & Adagio & $\phi$ & & \\
\hline Allegro & $\phi$ & & & Allegro & $2 / 4$ & & \\
\hline $\begin{array}{l}\text { Allegro tempo } \\
\text { di Menuetto }\end{array}$ & $3 / 4$ & & & Allegro & $2 / 4$ & & \\
\hline $\begin{array}{l}\text { Sonata } 7 \mathbf{m a} \\
\text { ex Dis moll } \\
\text { [Johann } \\
\text { Philipp } \\
\text { Kirnberger, } \\
\text { Sonata in E } \\
\text { flat minor] }\end{array}$ & & fl, b.c. & $\begin{array}{l}\text { D-B Mus. } \\
9953 \text { Rara }\end{array}$ & $\begin{array}{l}\text { Sonata } \\
\text { Septima [in } \\
\text { Fis] } \\
\text { [Johann } \\
\text { Philipp } \\
\text { Kirnberger, } \\
\text { Sonata in F } \\
\text { sharp major] }\end{array}$ & & fl, b.c. & \\
\hline Adagio & $\mathrm{C}$ & & & Adagio & $3 / 8$ & & \\
\hline Allegro & $2 / 4$ & & & Allegro & $3 / 8$ & & $\begin{array}{l}\text { movt III } \\
\text { Kirnberger, } \\
\text { Sonata in } \\
\text { F major in } \\
\text { transposition }\end{array}$ \\
\hline $\begin{array}{l}\text { Tempo di } \\
\text { Menuetto }\end{array}$ & $3 / 4$ & & & Presto & $\phi$ & & $\begin{array}{l}\text { movt II } \\
\text { Kirnberger } \\
\text { Sonata in } \\
\text { F major in } \\
\text { transposition }\end{array}$ \\
\hline [Var. 1] & $3 / 4$ & {$[\mathrm{fl}]$} & & & & & \\
\hline [Var. 2] & $3 / 4$ & [f] & & & & & \\
\hline $\begin{array}{l}\text { Sonata 8va } \\
\text { [in F sharp] } \\
\text { [Johann } \\
\text { Philipp } \\
\text { Kirnberger, } \\
\text { Sonata in F } \\
\text { sharp major] }\end{array}$ & & fl, b.c. & & $\begin{array}{l}\text { Sonata 8va ex } \\
\text { Dis moll } \\
\text { [Johann } \\
\text { Philipp } \\
\text { Kirnberger, } \\
\text { Sonata in E } \\
\text { flat minor] } \\
\end{array}$ & & fl, b.c. & $\begin{array}{l}\text { D-B Mus. } \\
9953 \text { Rara }\end{array}$ \\
\hline Adagio & $3 / 8$ & & & Adagio & $\mathrm{C}$ & & \\
\hline
\end{tabular}




\begin{tabular}{|c|c|c|c|c|c|c|c|}
\hline Allegro & $3 / 8$ & & $\begin{array}{l}\text { movt III } \\
\text { Kirnberger, } \\
\text { Sonata in } \\
\text { F major in } \\
\text { transposition }\end{array}$ & Allegro & $2 / 4$ & & \\
\hline Presto & $\phi$ & & $\begin{array}{l}\text { movt II } \\
\text { Kirnberger, } \\
\text { Sonata in } \\
\text { F major in } \\
\text { transposition }\end{array}$ & $\begin{array}{l}\text { Tempo di } \\
\text { Menuetto }\end{array}$ & $3 / 4$ & & \\
\hline & & & & [Var. 1] & & {$[\mathrm{fl}]$} & \\
\hline & & & & [Var. 2] & & [f] & \\
\hline$[$ Sonata in $\mathbf{d}]$ & & fl, b.c. & & & & & \\
\hline $\begin{array}{l}\text { [no agogic } \\
\text { designation of } \\
\text { the movt] }\end{array}$ & $3 / 8$ & & & & & & \\
\hline $\begin{array}{l}\text { [no agogic } \\
\text { designation of } \\
\text { the movt] }\end{array}$ & $2 / 4$ & & & & & & \\
\hline $\begin{array}{l}\text { [no agogic } \\
\text { designation of } \\
\text { the movt] }\end{array}$ & $3 / 8$ & & & & & & \\
\hline $\begin{array}{l}\text { [Filippo Ruge, } \\
\text { Sonata no. } 2 \\
\text { in D from VI } \\
\text { Duetti a Due } \\
\text { Flauti Traversi } \\
\text { composta Dell } \\
\text { Sigr. Filippo } \\
\text { Ruge] }\end{array}$ & & $2 \mathrm{fl}$ & $\begin{array}{l}\text { D-KA, Mus. } \\
\text { Hs. } 269 \text {, } \\
\text { DK-Kk mu } \\
6211.1240\end{array}$ & $\begin{array}{l}\text { [Filippo Ruge, } \\
\text { Sonata no. } 2 \\
\text { in D from VI } \\
\text { Duetti a Due } \\
\text { Flauti Traversi } \\
\text { composta Dell } \\
\text { Sigr. Filippo } \\
\text { Ruge] }\end{array}$ & & $2 \mathrm{fl}$ & $\begin{array}{l}\text { D-KA, Mus. } \\
\text { Hs. 269, } \\
\text { DK-Kk mu } \\
6211.1240\end{array}$ \\
\hline $\begin{array}{l}\text { Flauto 1mo, } \\
\text { Sostenuto } \\
{[\text { in D] }}\end{array}$ & $3 / 4$ & & & $\begin{array}{l}\text { Flauto 2do, } \\
\text { Sostenuto } \\
{[\text { in D] }}\end{array}$ & $3 / 4$ & & \\
\hline Con spirito & $\mathrm{C}$ & & & Con spirito & $\mathrm{C}$ & & \\
\hline $\begin{array}{l}\text { [Filippo Ruge, } \\
\text { Sonata no. } 5 \\
\text { in C from VI } \\
\text { Duetti a Due } \\
\text { Flauti Traversi } \\
\text { composta Dell } \\
\text { Sigr. Filippo } \\
\text { Ruge] }\end{array}$ & & $2 \mathrm{fl}$ & $\begin{array}{l}\text { D-KA, Mus. } \\
\text { Hs. } 269 \text {, } \\
\text { DK-Kk mu } \\
6211.1240\end{array}$ & $\begin{array}{l}\text { [Filippo Ruge, } \\
\text { Sonata no. } 5 \\
\text { in C from VI } \\
\text { Duetti a Due } \\
\text { Flauti Traversi } \\
\text { composta Dell } \\
\text { Sigr. Filippo } \\
\text { Ruge] }\end{array}$ & & $2 \mathrm{fl}$ & $\begin{array}{l}\text { D-KA, Mus. } \\
\text { Hs. } 269 \text {, } \\
\text { DK-Kk mu } \\
6211.1240\end{array}$ \\
\hline $\begin{array}{l}\text { Posato assai } \\
{[\text { in C] }}\end{array}$ & $3 / 8$ & & & $\begin{array}{l}\text { Posato assai } \\
{[\text { in } C]}\end{array}$ & $3 / 8$ & & \\
\hline Bizzaro & $\mathrm{C}$ & & & Bizzaro & $\mathrm{C}$ & & \\
\hline
\end{tabular}


The composers of the flute sonatas contained in these two anthologies have only been identified in part. They include Frederick the Great (I7I2-86, Sonata in G minor), ${ }^{23}$ Friedrich Hartmann (I727-95) or Christian Ernst Graf (I723-I804) in the case of the Sonata in C major, ${ }^{24}$ Filippo Ruge $(c .1725-c .1767$, duetti in D major and C major from VI Duetti a Due Flauti Traversi), ${ }^{25}$ Johann Philipp Kirnberger (the above-mentioned sonatas in E flat minor and F sharp major). ${ }^{26}$ Works for transverse flute are not very numerous in Kirnberger's output. ${ }^{27}$ They include, first and foremost, trio sonatas, sonatas for flute and b.c. and for solo flute, as well as minuets and forlanas. ${ }^{28}$

Out of Kirnberger's ten sonatas for flute and basso or b.c. currently known to us, ${ }^{29}$ all but one are found in a manuscript from the music collection of Anna Amalia Hohenzollern, ${ }^{30}$ as well as several other copies and one print. The only one printed in the composer's lifetime was a sonata in F major published by Friedrich Wilhelm Birnstiel in Berlin (I763) as II. Sonata per il Flauto Traverso con Basso..$^{3 \mathrm{I}}$ On the basis of the sources available to date, we can conclude that the two flute pieces by Kirnberger which attracted the greatest interest were the sonatas in $\mathrm{F}$ major and B flat major (nos. 2 and 8 in Table 2).

Table 2. Sonatas for flute and basso by Johann Philipp Kirnberger

\begin{tabular}{|c|c|c|c|c|c|c|c|}
\hline \multirow{2}{*}{$\frac{\text { No. }}{1 .}$} & \multirow{2}{*}{$\begin{array}{l}\text { Title } \\
\text { Sonata in } \\
\text { G major }\end{array}$} & \multicolumn{6}{|l|}{ Shelf marks } \\
\hline & & $\begin{array}{l}\text { D-B Am.B } \\
479 \text { (13) }\end{array}$ & & & & & \\
\hline 2. & $\begin{array}{l}\text { Sonata in } \\
\text { F major }\end{array}$ & $\begin{array}{l}\text { D-B Am.B } \\
479 \text { (14) }\end{array}$ & $\begin{array}{l}\text { DK-Kk mu } \\
6210.2930\end{array}$ & B-Bc 5570 & $\begin{array}{l}\text { as F sharp } \\
\text { major: } \\
\text { PL-TAb } 44\end{array}$ & $\begin{array}{l}\text { as F sharp } \\
\text { major: } \\
\text { PL-TAb } 45\end{array}$ & $\begin{array}{l}\text { Prints: } \\
\text { D-Bsa, SA } \\
4101 ; \\
\text { D-Rp; } \\
\text { D-Bsommer, } \\
\text { Mus.pr. } \\
\text { Kirnberger 2 }\end{array}$ \\
\hline
\end{tabular}

23 PL-TAb 44, Sonata Terza.

24 PL-TAb 45, Sonata Prima.

25 PL-TAb 44, Flauto Primo, Sostenuto; PL-TAb 45, Flauto 2do, Sostenuto.

26 PL-TAb 44, Sonata 7 ma ex Dis-moll, Sonata 8va [in F sharp major]; PL-Tab 45, Sonata Septima [in F sharp major], Sonata 8va ex Dis-moll.

27 Unfortunately, no catalogue of the composer's works has been compiled to date.

28 Cf. Peter Wollny, 'Kirnberger, Kirnberg, Kernberg, Johann Philipp', in: Die Musik in Geschichte und Gegenwart, Personenteil, ed. Ludwig Finscher, vol. 10, Kassel 2003, cols. 171-173.

29 The sonatas are variously described as works for flute and basso or for flute and b.c. Ten of Kirnberger's sonatas for flute and basso have been published in our times (but not as critical source editions) by Henrik Wiese in Winterthur (2002-2008 Amadeus Verlag).

30 Cf. D-B Am.B 479 (see Table 2).

31 RISM 469410100, 990033651. 


\begin{tabular}{|c|c|c|c|c|c|c|}
\hline 3. & $\begin{array}{l}\text { Sonata in } \\
\text { G minor }\end{array}$ & $\begin{array}{l}\text { D-B Am.B } \\
479(25)\end{array}$ & $\begin{array}{l}\text { D-Bsa SA } \\
4100\end{array}$ & & & \\
\hline 4. & $\begin{array}{l}\text { Sonata in } \\
\text { G major }\end{array}$ & $\begin{array}{l}\text { D-B Am.B } \\
479(26)\end{array}$ & $\begin{array}{l}\text { DK-Kk mu } \\
6210.2930\end{array}$ & & & \\
\hline 5. & $\begin{array}{l}\text { Sonata in } \\
\text { G major }\end{array}$ & $\begin{array}{l}\text { D-B Am.B } \\
479(27)\end{array}$ & & & & \\
\hline 6. & $\begin{array}{l}\text { Sonata in } \\
\text { E minor }\end{array}$ & $\begin{array}{l}\text { D-B Am.B } \\
479 \text { (28) }\end{array}$ & $\begin{array}{l}\text { as E flat } \\
\text { minor: D-B } \\
\text { Mus. } 9953 \\
\text { Rara }\end{array}$ & $\begin{array}{l}\text { as E flat } \\
\text { minor: } \\
\text { PL-TAb } \\
44\end{array}$ & $\begin{array}{l}\text { as E flat } \\
\text { minor: } \\
\text { PL-TAb } 45\end{array}$ & \\
\hline 7. & $\begin{array}{l}\text { Sonata in } \\
\text { G major }\end{array}$ & $\begin{array}{l}\text { D-B Am.B } \\
479(29)\end{array}$ & & & & \\
\hline 8. & $\begin{array}{l}\text { Sonata in } \\
\text { B flat } \\
\text { major }\end{array}$ & $\begin{array}{l}\text { D-B Am.B } \\
479(30)\end{array}$ & $\begin{array}{l}\text { DK-Kk mu } \\
6210.2930\end{array}$ & $\begin{array}{l}\text { B-Bc } \\
26347\end{array}$ & $\begin{array}{l}\text { D-Ju } \\
\text { Ms.Conc. } \\
\text { Acad.31 }\end{array}$ & \\
\hline 9. & $\begin{array}{l}\text { Sonata in } \\
\text { C major }\end{array}$ & $\begin{array}{l}\text { D-B Am.B } \\
479(31)\end{array}$ & $\begin{array}{l}\text { D-Bsa SA } \\
4099\end{array}$ & & & \\
\hline 10. & $\begin{array}{l}\text { Sonata in } \\
\text { C major }\end{array}$ & $\begin{array}{l}\text { DK-Kk mu } \\
6210.2930\end{array}$ & & & & \\
\hline
\end{tabular}

THE SONATA IN E FLAT MINOR IN THE PODHORCE MANUSCRIPTS

The Podhorce manuscripts contain Kirnberger's flute Sonata in E flat minor (see no. 6 in Table 2), hitherto known only from a Berlin manuscript (D-B Mus. 9953 Rara) dated $c .1775-c .1800 . .^{32}$ In both sources, it is a piece in three movements (Adagio-Allegro-Minuet with variations). A comparative study of the sonata versions found in the sources from Berlin and Podhorce reveals some minor differences, with the flute part and the bass accompaniment being rather more ornamented in the Podhorce version. In turn, it should be noted that the E flat minor Sonata substantially matches Kirnberger's E minor Sonata known from the manuscript D-B Am.B 479 (28).

In the Podhorce manuscript, the first movement is about a dozen bars longer than in the Berlin source: five bars were added at the start of the movement (bars 7-I2) and the soloist's final cadenza is written out, as is typical of all the compositions in the collection from Podhorce. Bars 7-I2 are of special interest, since they were borrowed from another work by Kirnberger, the abovementioned Sonata in E minor (see no. 6 in Table 2) found in a manuscript from the collection of Anna Amalia Hohenzollern

32 Sonta $\mathrm{Es}^{\mathrm{mol}} \mid$ per il | Flauto Traverso Solo | e | Basso | dell Sigre Joh: Phl: Kirnberger | [opening note of the Adagio movement] | [round stamp]: Ex | Biblioth [eca] Regia | Berolinens [is]. The manuscript was once owned by the teacher, collector and librarian Georg Poelchau (1773-1836). 
(1723-87) and dated to the second half of the eighteenth century (c.1760-c.I800). As mentioned above, the Sonata in E flat minor is an almost exact replica of Kirnberger's Sonata in $\mathrm{E}$ minor (transposed a minor second down). Interestingly, the differences between the E minor and E flat minor sonatas in the Berlin sources D-B 9953 Rara and D-B Am. B 479 (28), copied by one and the same scribe (Schober), ${ }^{33}$ are smaller than in the case of the E flat minor Sonata variant from Podhorce. One exception concerns bars 7-I2, missing from D-B 9953 Rara, but found in the E minor Sonata and in the E flat minor version from Podhorce (see Examples Ia-IC).

Example ra. Excerpt from the Sonata in E flat minor, movt I, Adagio, bars 6, I3, D-B 9953 (Rara)
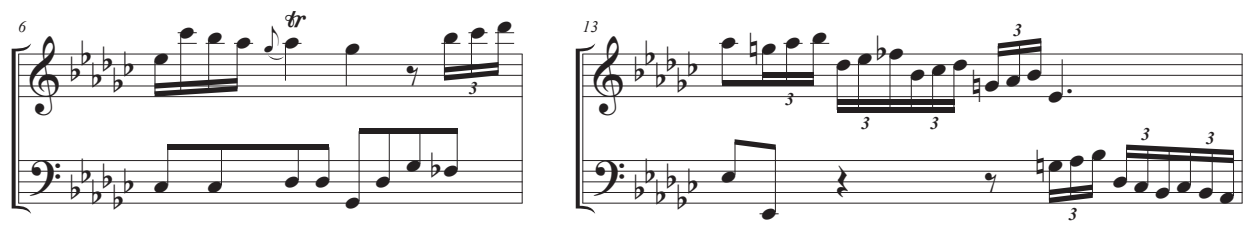

Example rb. Excerpt from the Sonata in E minor, movt I, Adagio, bars 6-13, D-B Am 479 (28). The fragment missing from D-B 9953 (Rara), but common to D-B 479 (28) and P-TAb 44, 45, is placed in square brackets

Fl

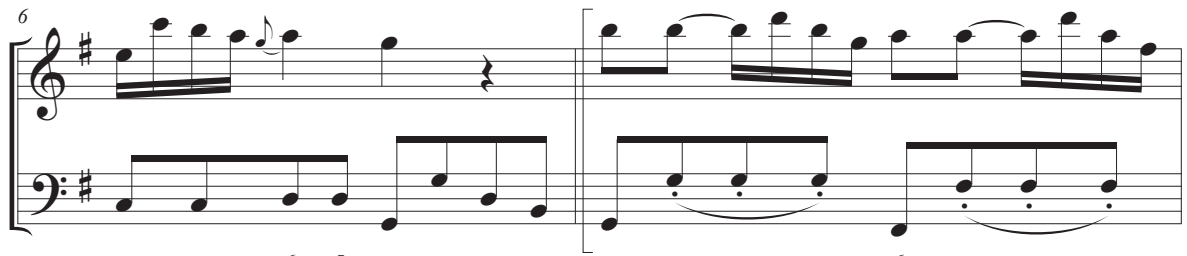
$\begin{array}{ll}6 & 5 \\ 4 & 3\end{array}$

6

$\mathrm{F}$

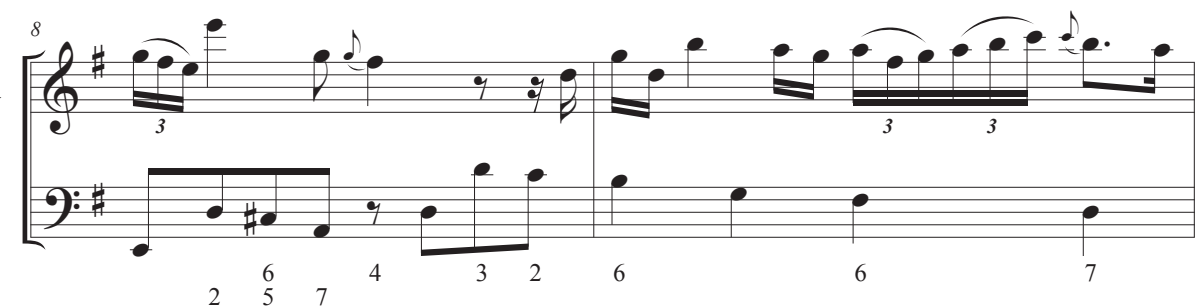

33 Cf. RISM 1001138692 and RISM 452506088. 
Fl

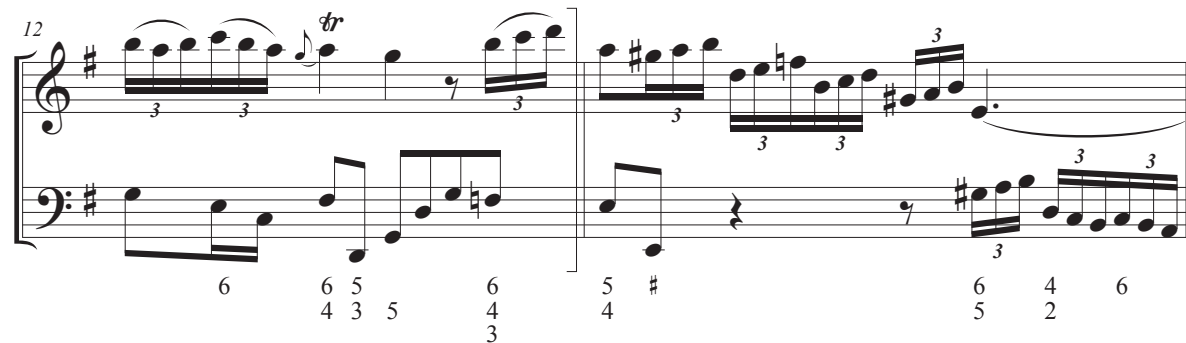

Example ic. Excerpt from the Sonata in E flat minor, movt I, Adagio, bars 6-I3, PL-TAb 44, 45. The fragment missing from D-B 9953 (Rara), but common to D-B 479 (28) and PL-TAb 44, 45, is placed in square brackets

$\mathrm{Fl}$

B

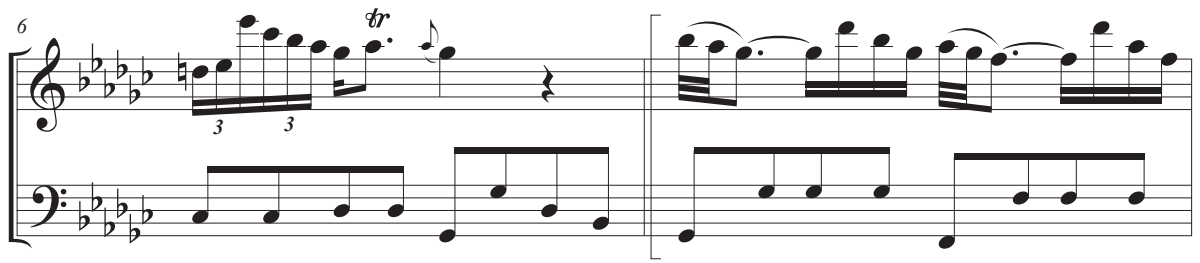

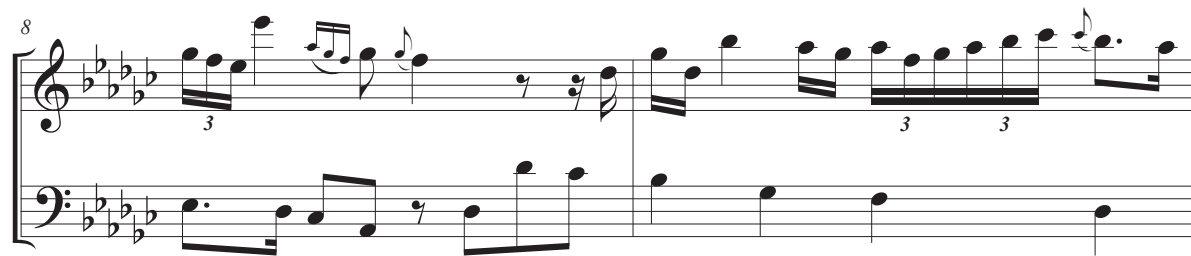

$\mathrm{Fl}$
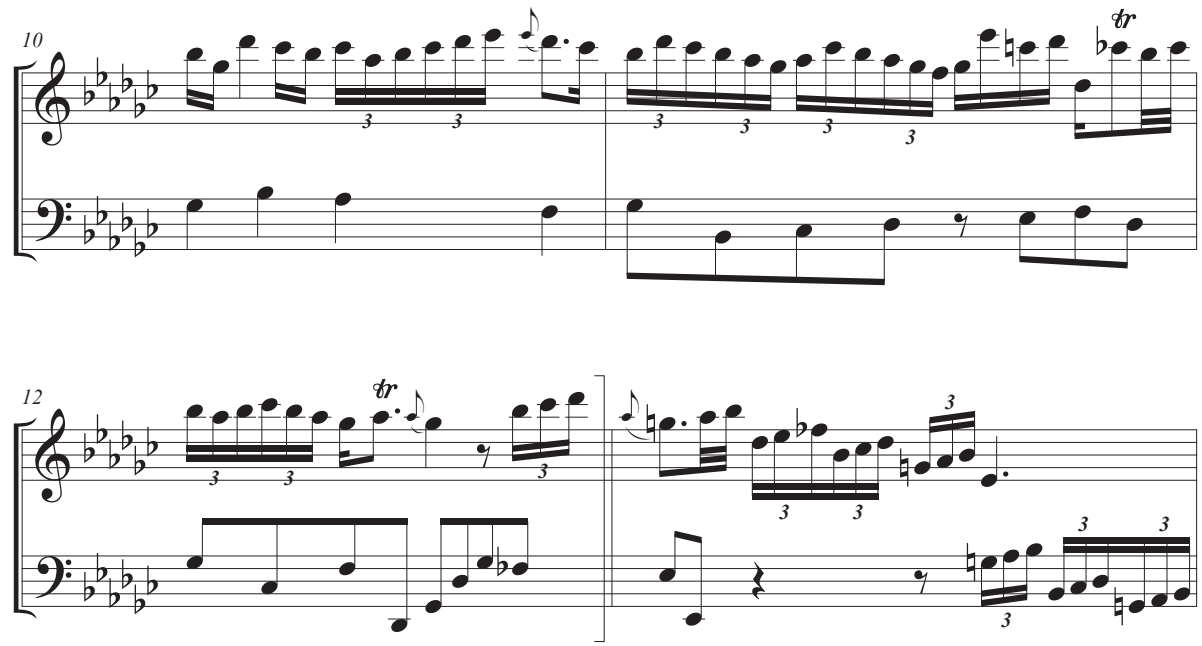
In the second movement, the sources mainly differ in the figuring of the bass, which in the Podhorce manuscripts diverges from the Berlin version of the same piece and from the Sonata in E minor. The flute part, on the other hand, is principally the same (see Examples 2a-2c). Moreover, in the Berlin variant of the E flat minor Sonata, two bars were added in the second movement (bars 39, 40) out of the four (bars 39-42) present in the E minor Sonata. This four-bar fragment is completely missing from the Podhorce version.

Example 2a. Excerpt from the Sonata in E flat minor, movt II, Allegro, bars I-IO, D-B 9953 (Rara)
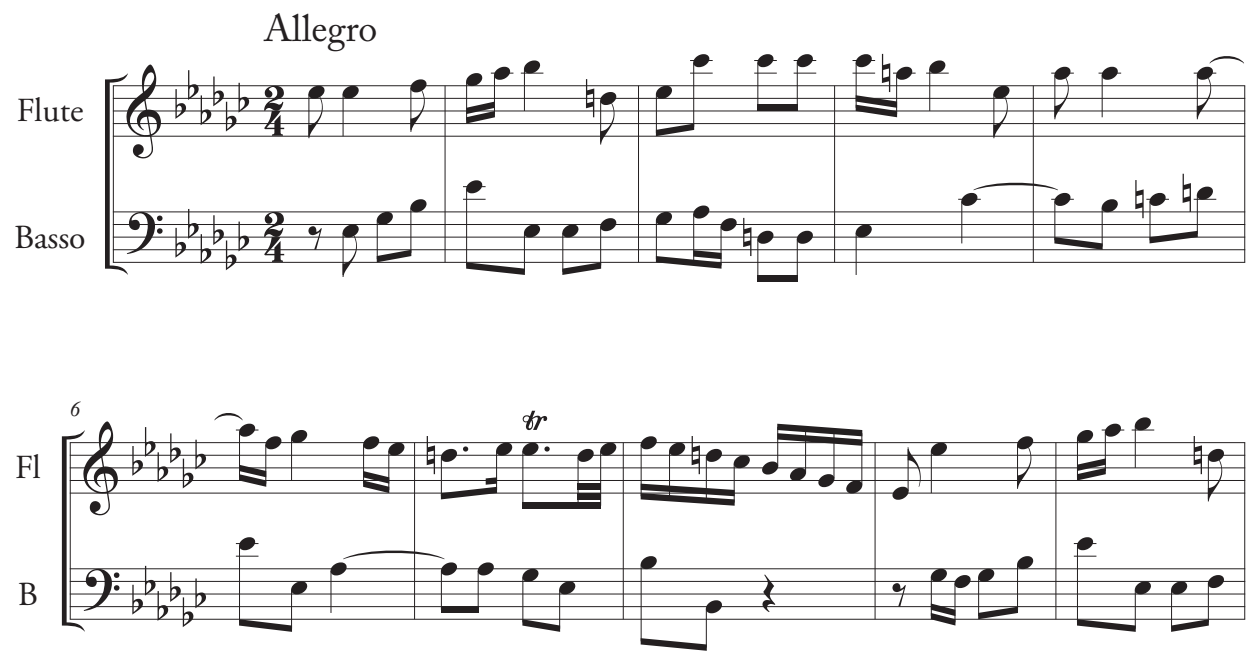

Example 2b. Excerpt from the Sonata in E flat minor, movt II, Allegro, bars I-IO, D-B Am 479 (28)
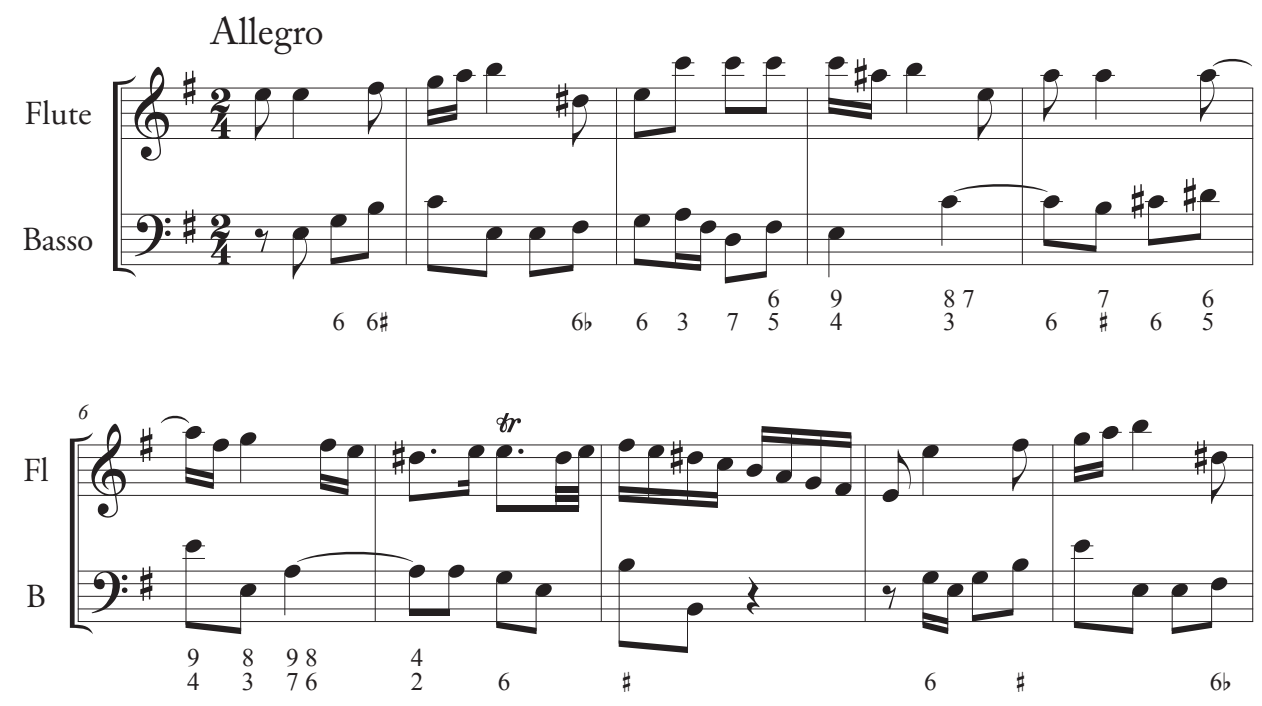
Example 2c. Excerpt from the Sonata in E flat minor, movt II, Allegro, bars I-IO, PL-TAb 44, 45

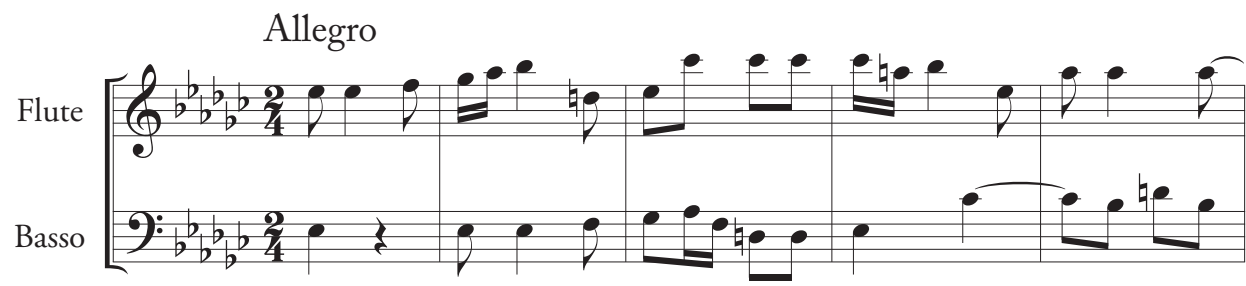

Fl

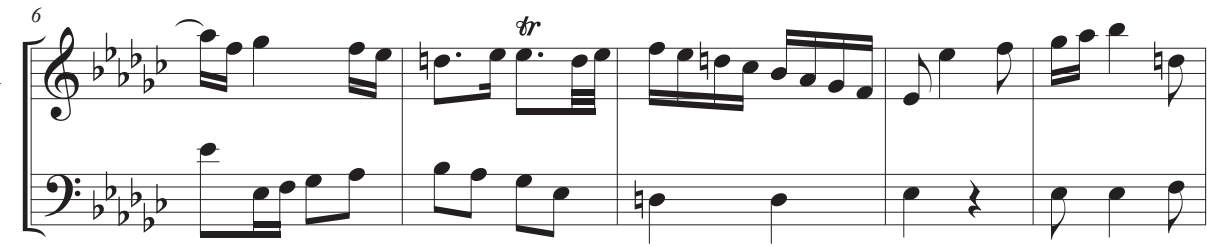

The third movement, a Minuet with Variations, in the Podhorce manuscript comprises only two out of the five variations found in both Berlin sources. As in the Sonata in E minor, these variations have only been notated as a solo voice. In both PL-TAb 44 and PL-TAb 45, the second variation is followed by a blank section of the page, which would have sufficed to enter at least one more variation. For reasons unknown, this was not done. There are few differences between the sources in this last movement, mostly concerning the flute part, where the note values are more subdivided, especially in the variations.

Example 3a. Excerpt from the Sonata in E flat minor, movt III, Minuet with Variations, variation 2, bars $15-20$, D-B 9953 (Rara)

Fl

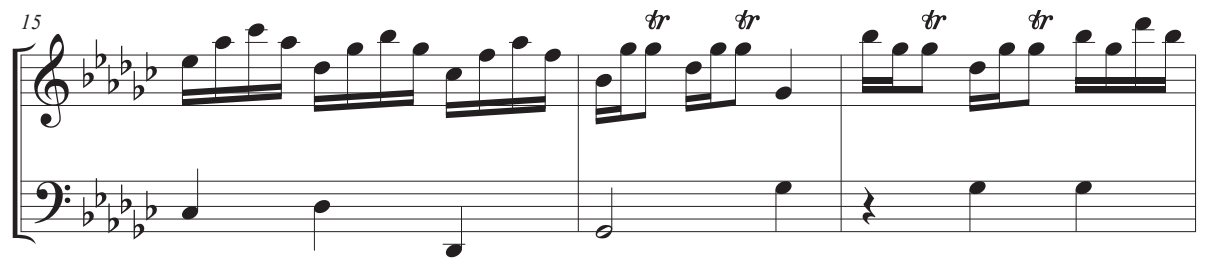

Fl

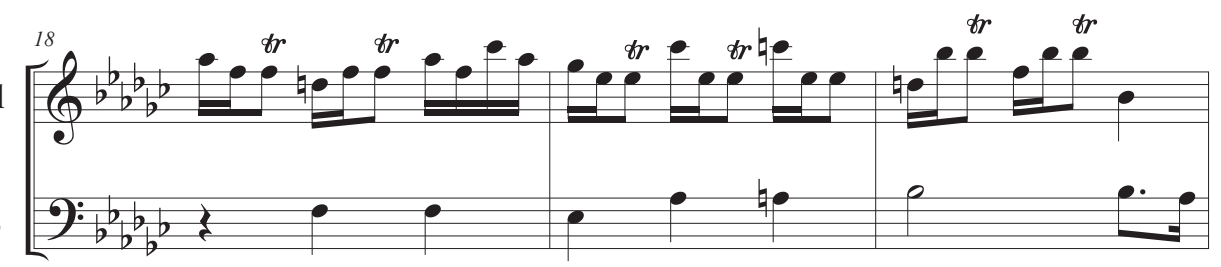


Example 3 b. Excerpt from the Sonata in E minor, movt III, Minuet with Variations, variation 2, bars I5-20, D-B Am 479 (28). The b.c. part has been supplemented on the basis of the part notated in the Minuet (added notes are placed in square brackets)

$\mathrm{Fl}$

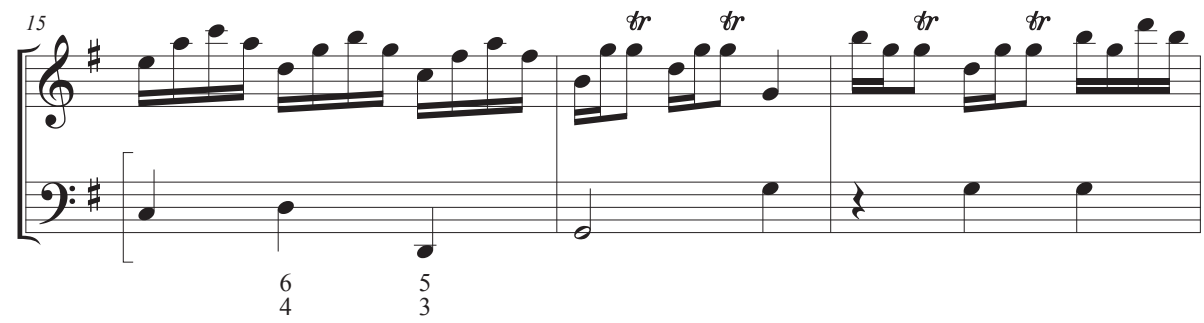

$\mathrm{Fl}$

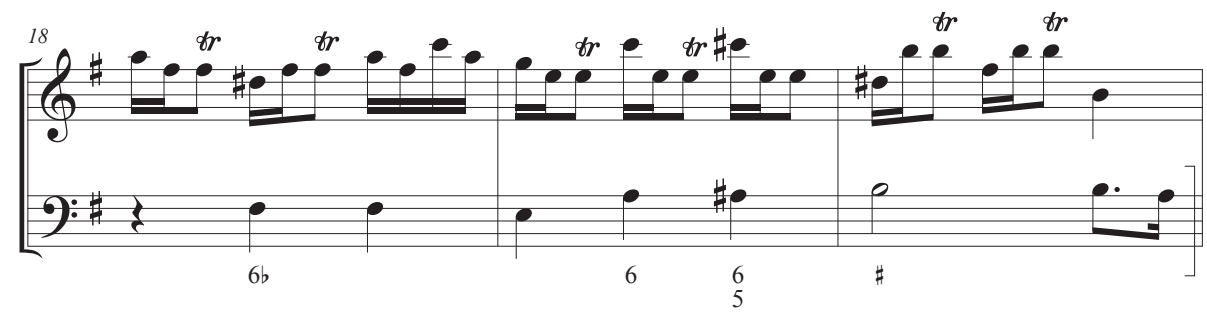

Example 3c. Excerpt from the Sonata in E flat minor, movt III, Minuet with Variations, variation 2, bars I5-20, PL-TAb 44, 45. The b.c. part has been supplemented on the basis of the part notated in the Minuet (added notes are placed in square brackets)

$\mathrm{Fl}$

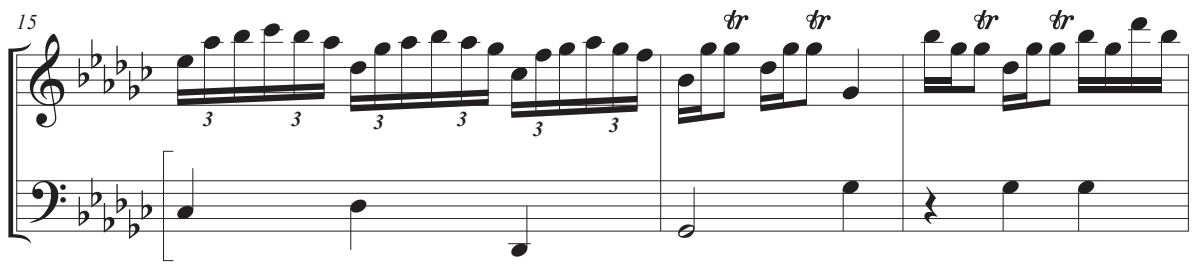

$\mathrm{Fl}$

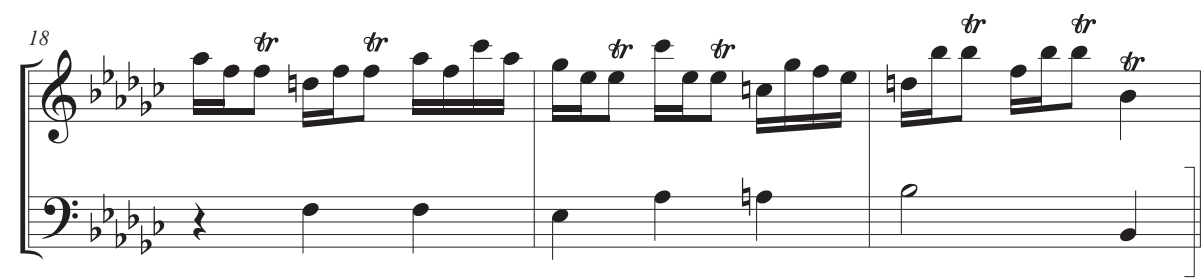

In the manuscript from Podhorce, as in D-B 9953 Rara, the bass figuring found in the $\mathrm{E}$ minor Sonata was not entered. Divergencies and variant solutions between the Podhorce and Berlin versions of the E flat minor Sonata do not always result 
from simple octave transpositions, parts being shifted by a third, or from equivalent rhythmic subdivisions. In several cases, the Podhorce version contains autonomous melodic and rhythmic solutions, mostly meant to enrich the music with more refined ornamentation. The copyist of the E flat minor Sonata from PL-TAb undoubtedly knew both the E minor Sonata (see comments for the Adagio movement) and Kirnberger's piece in E flat minor. The chronology of these versions is an interesting problem, though apparently impossible to solve unequivocally on the basis of the sources currently at our disposal. Which of the two sonatas, in E minor or E flat minor, was the first one to be composed? E flat minor is a rare and unique key in Kirnberger's oeuvre, which suggests that the latter version came into being as a result of a fundamentally mechanical transposition of the E minor Sonata to another key. This thesis seems to be corroborated by Kirnberger's other work found in the Podhorce manuscripts.

\section{THE SONATA IN F SHARP MAJOR IN THE PODHORCE MANUSCRIPTS}

The anonymously notated F sharp major Sonata in PL-TAb 44 and 45 appears to be related to Kirnberger's Sonata in F major, which we know from several other sources (see no. 2 in Table 2). ${ }^{34}$ Indeed, two of the F sharp major movements in the Podhorce manuscripts (Allegro and Presto) are transpositions of movements from the Sonata in F major. The Adagio, instead, has not been identified yet, and it is not known from any musical source.

Let us begin the examination with the second movement Allegro of the F sharp major Sonata. This is derived from the third movement (Tempo di Minuetto) of Kirnberger's F major Sonata, with only some minor differences in the leading of the bass voice, consisting mainly in octave shifts and diminutions. The tendency to treat the solo and bass parts in a more ornamented manner, evident in the Sonata in E flat minor, is absent from the Podhorce F sharp major Sonata. In the flute part, there are virtually no differences between the F major and F sharp major Sonatas (only minor deviations in bars 25, 50, 69 and 78). Notably, the Allegro is ten bars longer than the Tempo di Minuetto from Kirnberger's F major Sonata. Two of these added bars contain relatively new material (bars 48-49, ${ }^{35}$ see Examples $4 \mathrm{a}$ and $4 \mathrm{~b}$ ), while the other, eight-bar segment is repeated at the end of the movement. ${ }^{36}$

34 Of the existing copies of this work, I have used the same Berlin manuscript as in the case of Kirnberger's E minor Sonata (D-B Am. B 479 from Anna Amalia Hohenzollern's music collection), where the Sonata in $\mathrm{F}$ major was entered by the same copyist (Schober).

35 Interestingly, the flute part in bar 48 is identical to the material in bars $66,67,72$ and 73 presented in other keys, whereas the bass part in bar 48 is different from that in those latter passages. The material of bar 49 is new.

36 Bars 62-69 are repeated in bars 70-75. 
Example 4a. Excerpt from the Sonata in F major, movt III, Tempo di Minuetto, bars 40-59,

D-B Am 479 (I4). The segment in square brackets is the modified one, extended to cover two bars in PL-TAb 44, 45

$\mathrm{Fl}$

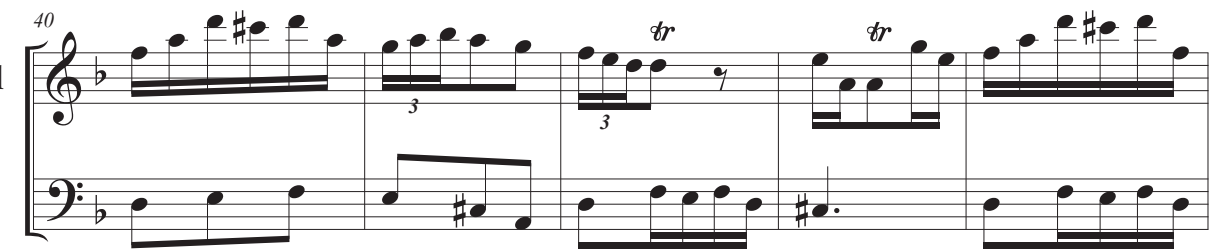

6b 6

$6 \stackrel{7}{\sharp}$

6

6

6

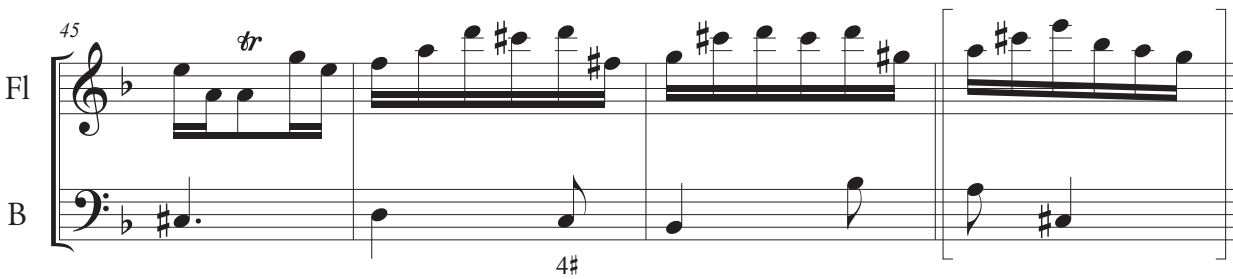

6

26

$6 b$
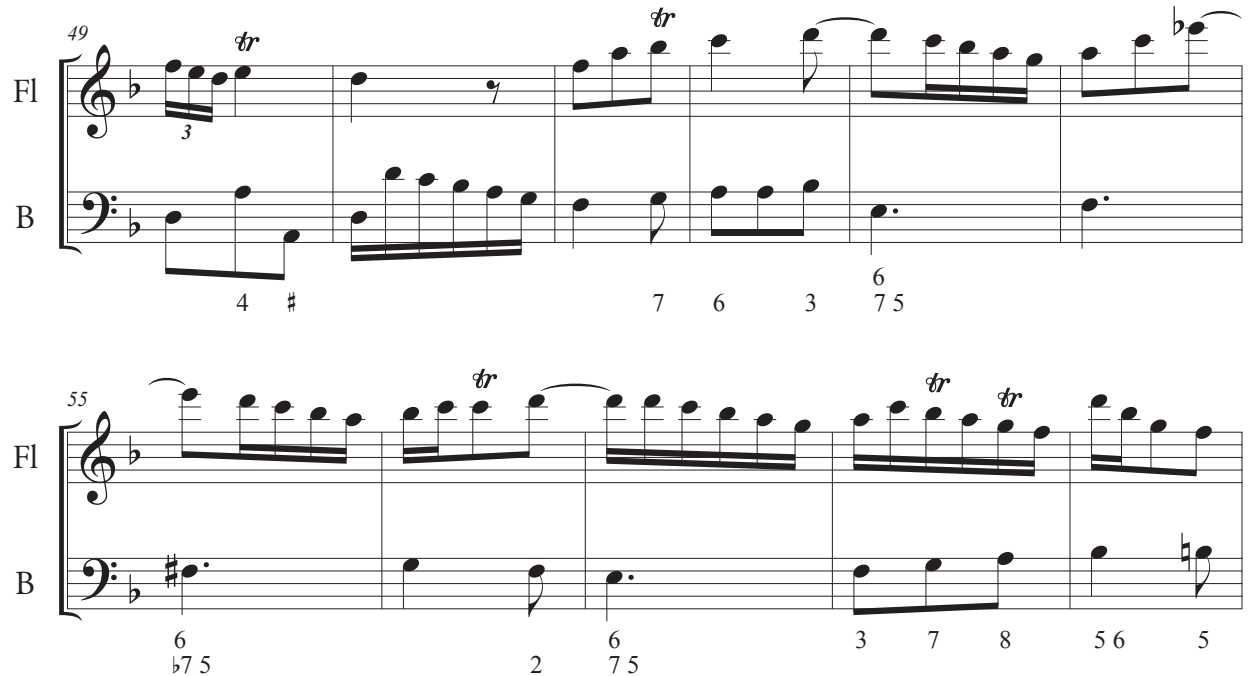
Example 4b. Excerpt from the Sonata in F sharp major, PL-TAb 44, 45, movt II, Allegro, bars 40-60. The bars in square brackets were added in the Podhorce manuscript

Fl

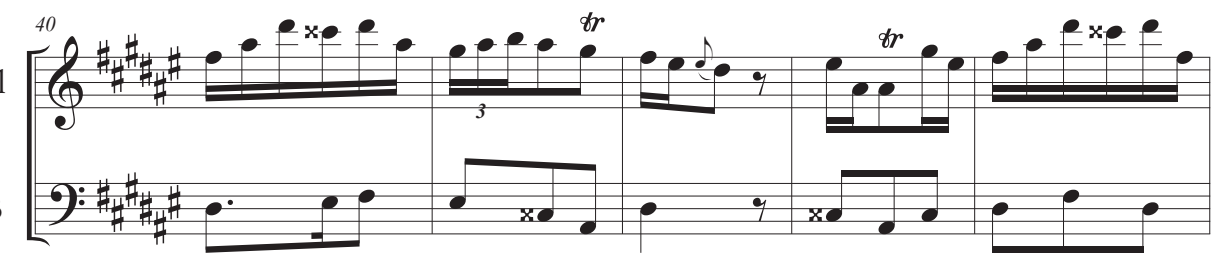

Fl

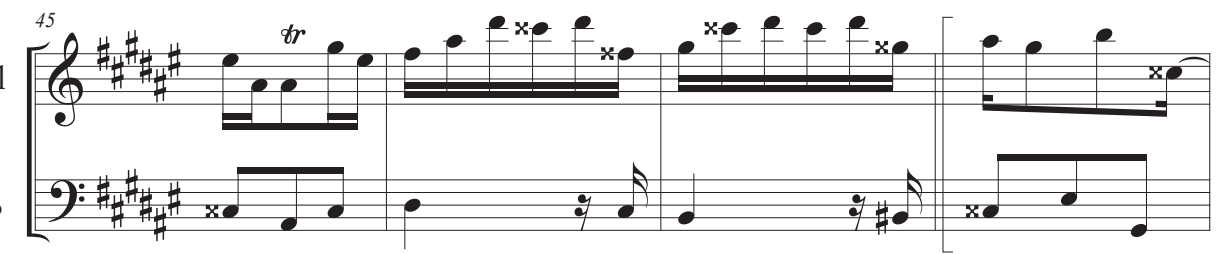

Fl

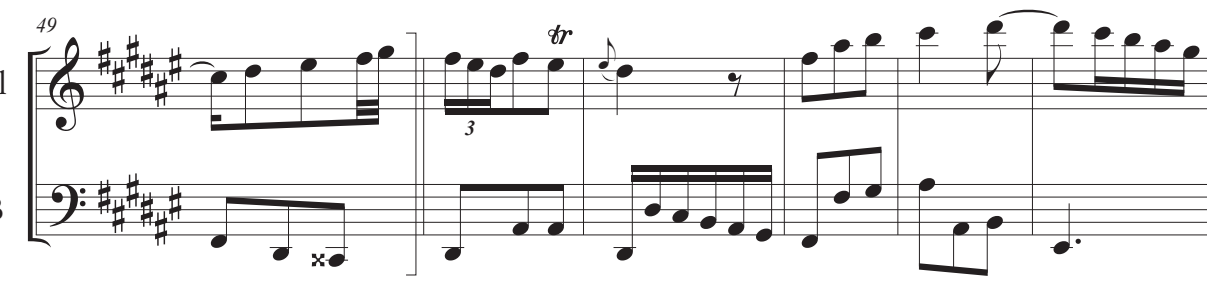

$\mathrm{Fl}$

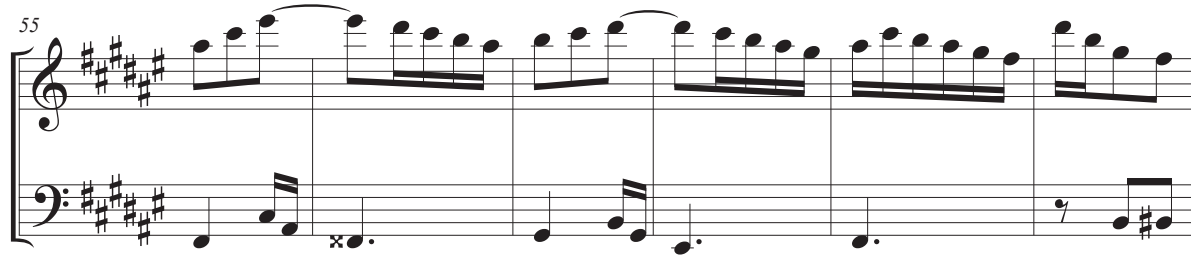

The third movement Presto from the Sonata in F sharp major is based on the second movement Allegro of Kirnberger's F major Sonata, with minor differences in both the flute and bass parts. In the Podhorce version of this movement, there is no distinct tendency to make the parts more ornamented, which may be due to its already fast tempo. The version from PL-TAb is three bars shorter than the Berlin one: PL-TAb does not include the seventh repetition of the material of bar $24,{ }^{37}$ the third

37 This material is presented in the two sources in different keys in bars 3, 5, 33, 35, 65 and 67 (bar numbering as in the Sonata in F sharp major). 
repetition of bar $47^{38}$ or the new material in bar 76 . Another difference between the two manuscripts concerns four bars from the central section of the movement (bars $42-45$ in the F sharp major and bars $43-46$ in the F major Sonata). The latter piece has a figured bass which is missing from the sonatas found in PL-TAb (see Examples $5 \mathrm{a}$ and $5 \mathrm{~b})$.

Example 5a. Excerpt from the Sonata in F major, movt II, Allegro, bars I-I6, D-B Am 479 (I4)

Allegro

Flute

Basso

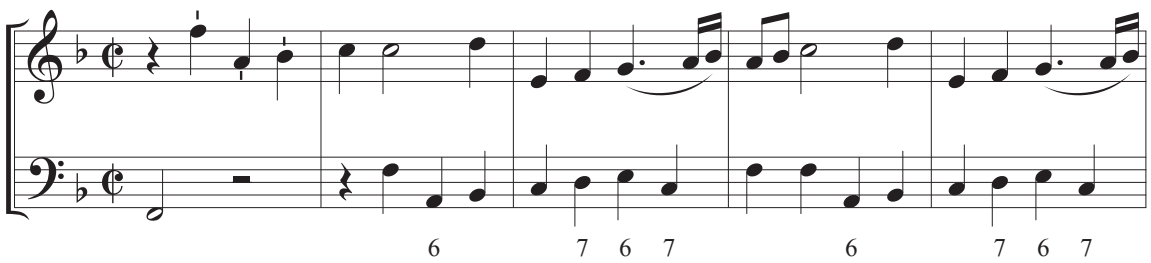

$\mathrm{Fl}$

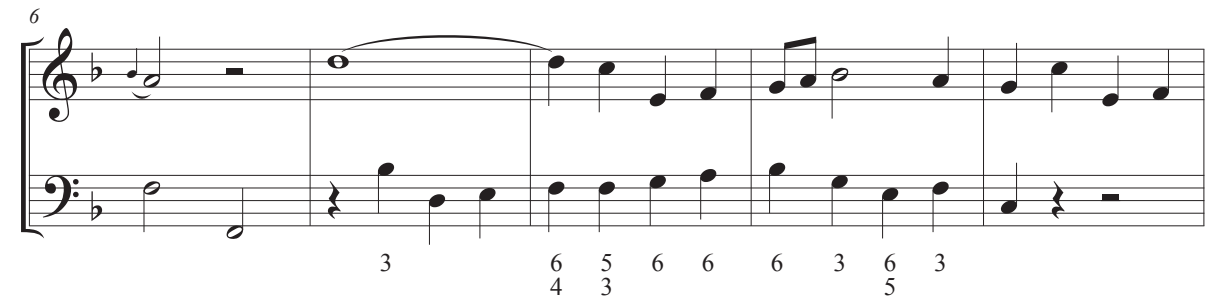

$\mathrm{Fl}$

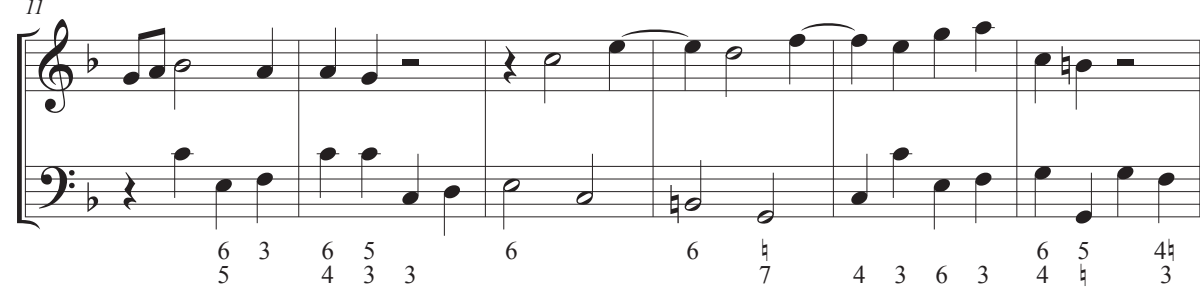

Example 5b. Excerpt from the Sonata in F sharp major, movt III, Presto, bars I-I6, PL-TAb 44, 45

Presto

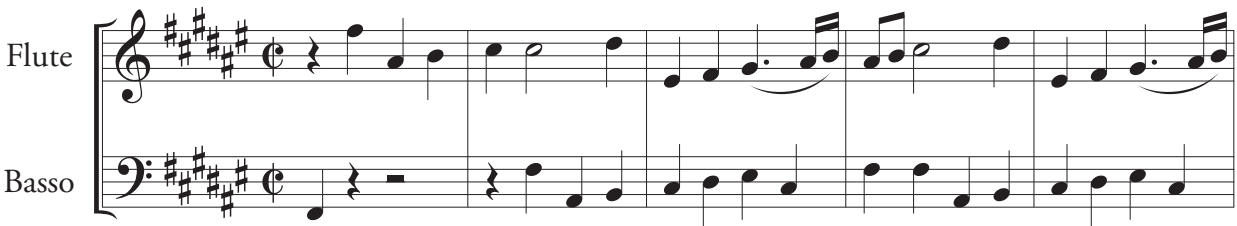

38 In PL-TAb, bar 47, omitted from D-B Am. B 479 (14), appears in bars 44 and 46. This material is also presented twice in the F major Sonata, in bar 47 and also in bar 49 . 
Fl

B

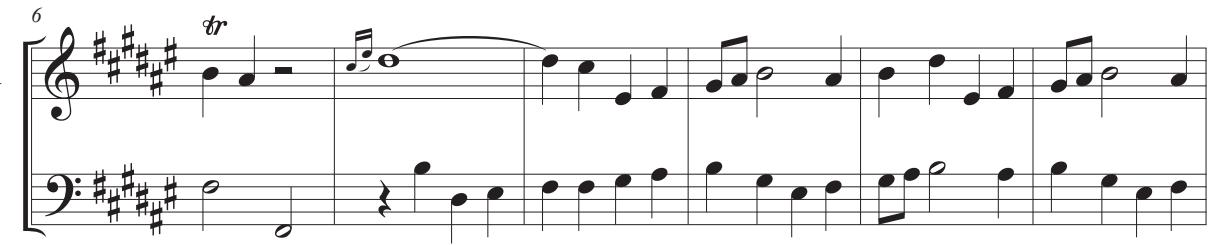

Fl

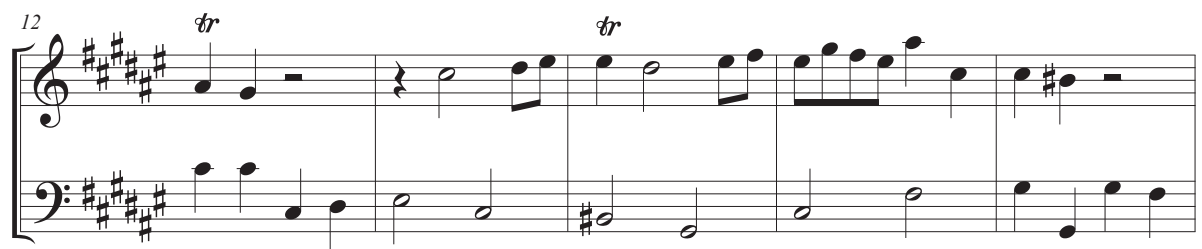

Comparison of the second and third movements of the Sonata in F sharp major from Podhorce with the corresponding two last movements of Kirnberger's Sonata in $\mathrm{F}$ major demonstrates, as in the case of the E flat minor and $\mathrm{E}$ minor Sonatas, the use of a technique of transposing the work to a key with multiple sharps or flats in the signature by almost mechanically shifting the whole piece by a given interval. There are only a few minor differences between the Allegro and Presto of the F major and F sharp major Sonatas. However, the version of the Sonata in F sharp major in the PL-TAb manuscripts is, to the best of my knowledge, unique to this particular music collection. In this version, the second and third movements of Kirnberger's F major Sonata are swapped around. Similar changes can be observed in several other sonatas from the Podhorce collection, ${ }^{39}$ and they may reflect innovations introduced by its copyist. It is not to be excluded that some hitherto unknown manuscript still contains a version of the Sonata in F sharp major with the movements in the same order as in the Sonata in F major.

The greatest difference between the F major and the Podhorce F sharp major Sonatas concerns the first movement (Adagio). Instead of the Adagio from the F major Sonata, the copyist added a different movement that has not been identified so far among works by either Kirnberger or any other composer. There are several similar examples in the Podhorce collection, in line with a tendency at that time to write instrumental pasticcios. ${ }^{40}$ In the case of the Podhorce collection, I believe that the

39 In PL-TAb 23, this is the case, for instance, with the Sonata terza g-moll by Frederick the Great, the movements of which were entered in the following sequence: II, I, III.

40 Examples of pasticcios in PL-TAb 45 include two pieces in E minor, Sonata quarta and quinta, and in PL-TAb 23 a Concerto Secondo in G major that combines the first movement of a flute concerto by J.J. Quantz, QV 4:4, with an Adagio and Allegro written by another, hitherto unidentified composer. Cf. also I. Bieńkowska, 'Osiemnastowieczna twórczość instrumentalna', p. 169. 
composer of these 'new' works consisting of a mosaic of movements from pieces by known composers, combined with movements that are possibly original, may have been a musician (perhaps a Kapellmeister?) in Wacław Piotr Rzewuski's music ensemble in Podhorce. ${ }^{41}$

Like the Sonata in E flat minor, the F sharp major Sonatas came into being by transposing the material of Kirnberger's Sonata in F major. Hence this is not the original form of the work, but a remake tailored to the needs of a local music ensemble. On the basis of the music sources kept at Tarnów Municipal Library, we may conclude that the technique of remaking music in various ways was characteristic of the instrumental works performed at Podhorce Castle. Especially frequent was the practice of reordering movements within a cycle and composing new movements. The surviving Sonata in F sharp major is an example of both.

The presence among the musical items from Podhorce of two sonatas in keys with a large number of sharps or flats in the signature means that Rzewuski's ensemble contained accomplished flautists capable of playing such complicated works. Compositions in A flat major and F minor, for instance, were written by Pierre-Gabriel Buffardin during the mid-eighteenth century, probably with his gifted pupils Pietro Grassi Florio and Franz Joseph Götzel in mind. ${ }^{22}$ Unfortunately, we do not know the names of the Podhorce flautists, but given that works by Quantz and Kirnberger were played there, and that instruments made by Jean-Joseph Buffardin - Pierre-Gabriel's father - were used in the ensemble, it seems entirely plausible to suggest that the flautists there were also highly skilled and renowned throughout Europe.

The Podhorce music collection dates approximately from the years 1755-67, which means it was compiled after Kirnberger had left the Rzewuski court in Podhorce and possibly the Polish-Lithuanian Commonwealth as well. So how did the composer's sonatas find their way into the collection? Are the versions at our disposal earlier than the previously known Berlin records of these works? Answering these questions seems almost impossible until we have obtained further information.

41 The practice of combining movements written by different composers into a single new whole was known from the second half of the seventeenth century onwards. In the 1720s, the pasticcio technique became very widespread, and it continued to enjoy popularity until nearly the end of the century. It was applied primarily to operatic works, mainly Italian opera seria and buffo, but also to regional (French, English and German) varieties of the genre. The Italian term 'pasticcio' was first used by J.J. Quantz as early as 1725 (as he informs us in his autobiography of 1755, see: J.J. Quantz, 'Herrn Johann Joachim Quantzens Lebenslauf', p. 230). In instrumental music (though less frequently than in opera), popular and appreciated musical fragments were also combined into new wholes, which frequently enjoyed more popularity than pieces by a single composer. It is possible that at Podhorce Castle the pasticcio practice concerned not only instrumental music, but also opera productions, though we have no information on this as yet.

42 I am grateful to Wim Brabants for information about Buffardin's works: sonatas in A flat major and F minor appear in DK-Kk, mu 6210.1326 (RISM A/II 150205228), and a concerto in F minor in D-Dl, Mus.2-O-5, 4. (RISM A/II 212003581). 
However, two possible answers come to mind. These compositions may have been copied into PL-TAb 44 and 45 from earlier unbound music sources belonging to the Podhorce collection. One example of such repertoire transmission is the PL-TAb 23 manuscript from the same collection, containing works which have otherwise been preserved on loose sheets of paper. ${ }^{43}$ If this is true, Kirnberger's sonatas may have been preserved from the time of the musician's stay there. There is another possible scenario, namely, that the compositions were acquired later, from the private resources of musicians coming to Podhorce, or imported from abroad for the needs of the court ensemble.

The uncertain dating of the individual manuscripts comprising the four sonatas (in $\mathrm{E}$ minor, E flat minor, F major, and F sharp major) unfortunately makes their dates of composition similarly difficult to determine. The Podhorce manuscripts are undoubtedly the oldest source for the E flat minor Sonata known today, as well as the only (albeit transformed) record of Johann Philipp Kirnberger's Sonata in F sharp major.

\section{BIBLIOGRAPHY}

Bellermann, Johann Gottfried Heinrich. 'Briefe von Kirnberger an Forkel.' Allgemeine musikalische Zeitung 6 (I87I): 529-678 and 7 (I872): 44I-457.

Bieńkowska, Irena, introd. and ed. Sonaty Francesca Marii Cattaneo (I697-1758) oraz finali i duetto z rękopisu tarnowskiego (PL-TA 23). Warszawa: Instytut Muzykologii Uniwersytetu Warszawskiego, Wydawnictwo Naukowe Sub Lupa, 2018 (= Musica Revelata M/I).

Bieńkowska, Irena, introd. and ed. Sei Concerti a flauto traversiere obligato z rękopisu tarnowskiego (PL-TA 49-54). Warszawa: Instytut Muzykologii Uniwersytetu Warszawskiego, Wydawnictwo Naukowe Sub Lupa, 2019 (= Musica Revelata M/2).

Bieńkowska, Irena. 'Osiemnastowieczna twórczość instrumentalna z dawnej kolekcji muzykaliów w Podhorcach.' Barok. Historia-Literatura-Sztuka 26, nr I (2019): 165-184.

Borkowska, Maria. Leksykon zakonnic polskich epoki przedrozbiorowej. Vol. 3, Wielkie Księstwo Litewskie i Ziemie Ruskie Korony Polskiej. Warszawa: DiG, 2008.

Eitner, Robert. Biographisch-Bibliographisches Quellen-Lexikon der Musiker und Musikgelehrten. Leipzig: Breitkopf und Haertel, 1900-04.

Erdman, Jerzy. 'Kirnberger, Johann Philipp.' In: Encyklopedia Muzyczna PWM, ed. Elżbieta Dziębowska. Vol. 5, 89-90. Kraków: PWM, 1997.

Haymann, Christoph Johann Gottfried. Dresdens theils neuerlich verstorbene theils jetzt lebende Schriftsteller und Künstler wissenschaftlich classificirt nebst einem dreyfachen Register. Dresden: Waltherschen Hofbuchhandlung, I809.

Marpurg, Friedrich Wilhelm. Historisch-kritische Beyträge zur Aufnahme der Musik. Vol. I. Berlin: Joh. Jacob Schützens sel. Witwe, I754-55.

Marpurg, Friedrich Wilhelm. Legende einiger Musikheiligen. Breslau: Cölln am Rhein bey P. Hammern, 1786 .

43 See: Sonaty Francesca Marii Cattaneo, pp. 5-10. 
Paczkowski, Szymon. 'Bach and Poland in the Eighteenth Century.' Understanding Bach Io (2015): I23-I37.

Quantz, Johann Joachim. 'Herrn Johann Joachim Quantzens Lebenslauf von ihm selbst entworfen.' In: Friedrich Wilhelm Marpurg, Historisch-kritische Beyträge zur Aufnahme der Musik. Vol. I, ch. 3. Berlin: Joh. Jacob Schützens sel. Witwe, I755.

Reilly, Edward R. 'Pierre-Gabriel Buffardin.' In: Grove Music Online, https://doi.org/Io.Io93/ gmo/9781561592630.article.04264, accessed 7 January 2021.

Seiffert, Max. 'Notizen, "Aus dem Stammbuche Johann Philipp Kirnbergers".' Vierteljahrsschrift für Musikwissenschaft 5, no. 2 (I889): 365-37I.

Serwer, Howard. 'Kirnberger [Kernberg], Johann Philipp.' In: Grove Music Online, https:// doi.org/IO.IO93/gmo/9781561592630.article.I506I, accessed 7 January 202I.

Szczygielski, Wojciech. 'Poniński Józef.' In: Polski Stownik Biograficzny, ed. Emanuel Rostworowski. Vol. 28, 536. Wrocław-Kraków: Zakład Narodowy im. Ossolińskich, Wydawnictwo Polskiej Akademii Nauk, 1984-85.

Vogel, Benjamin. 'Do dziejów tradycji muzycznych zamku w Podhorcach.' Polski Rocznik Muzykologiczny I3 (2015): 99-I24.

Wollny, Peter. 'Kirnberger, Kirnberg, Kernberg, Johann Philipp.' In: Die Musik in Geschichte und Gegenwart, Personenteil, ed. Ludwig Finscher. Vol. IO, I70-I75. Kassel: Bärenreiter-Metzler, 2003.

Żórawska-Witkowska, Alina. Muzyka na polskim dworze Augusta III. Part I. Lublin: Polihymnia, 2012.

\section{NIEZNANE PRZEKAZY SONAT FLETOWYCH JOHANNA PHILIPPA KIRNBERGERA W KOLEKCJI MUZYKALIÓW Z PODHORCÓW}

W zbiorach Biblioteki Miejskiej w Tarnowie, Dział Starych Druków i Książki XIX-wiecznej, przetrwały rękopisy, PL-TAb 44 i 45, należące ongiś do kolekcji muzykaliów w Podhorcach, zawierające m.in. dwie sonaty na flet i basso Johanna Ph. Kirnbergera. Są to pierwsze, jak dotychczas, źródła pochodzące z terenu dawnej Rzeczpospolitej, które pośrednio potwierdzają dziesięcioletnią prawie działalność znakomitego teoretyka i kompozytora w naszym kraju. Rękopisy należy datować na lata pięćdziesiąte/pierwszą połowę sześćdziesiatych XVIII wieku. Utwory J.Ph. Kirnbergera to Sonata es-moll, której jedyny znany do tej pory przekaz znajdował się w zbiorach berlińskich (D-B Mus. 9953 Rara), oraz Sonata Fis-dur. W dotychczasowym dorobku Kirnbergera sonata w tonacji Fis-dur nie była znana. Porównanie Sonaty Fis-dur z Sonatą F-dur Kirnbergera dowodzi analogicznego do Sonaty es-moll i e-moll sposobu utworzenia przez tego kompozytora dzieła w tonacji z dużą liczbą znaków poprzez mechaniczne niemalże przesunięcie kompozycji o zadany interwał. Dostrzeżone warianty pomiędzy Sonatą F-dur i Fis-dur są nieliczne i nieznaczne. Przeprowadzone porównanie potwierdza, że sonata w takiej tonacji musiała znajdować się wśród dzieł niemieckiego kompozytora, poszerzając zasób jego kompozycji w tym gatunku do dwunastu. Wersja Sonaty Fis-dur, którą znamy z rękopisów PL-TAb, jest specyficzną dla danej kolekcji muzykaliów odmianą tego dzieła. Kompozycję zanotowano w postaci zniekształconej, zgodnie z praktyką przeróbek cha- 
rakterystyczną dla zespołu muzycznego w Podhorcach, zamieniając miejscami części dzieła, a nadto dodając nową, autorstwa innego twórcy, tworząc instrumentalne pasticcio. Niepewne datowanie poszczególnych rękopisów zawierających Sonaty e-moll, es-moll, F-dur, Fis-dur utrudnia, niestety, odpowiedź na pytanie o czas powstania dzieł. Niewątpliwie jednak przekaz podhorecki stanowi najwcześniejsze z obecnie znanych źródeł zawierających Sonatę es-moll i jedyny, choć zniekształcony przekaz Sonaty Fis-dur J.Ph. Kirnbergera.

Irena Bieńkowska

Keywords / słowa kluczowe: Johann Philipp Kirnberger, sonatas for flute and basso continuo / sonaty na flet i basso, Sonata in E flat minor / Sonata es-moll, Sonata in F sharp major / Sonata Fis-dur, Pidhirtsi / Podhorce, Wacław Piotr Rzewuski

Irena Bieńkowska, PhD, Habil., affiliated to the Institute of Musicology, University of Warsaw, focuses in her research on the musical culture of the Polish-Lithuanian Commonwealth in the seventeenth and eighteenth centuries, with particular emphasis on the history of secular aristocratic patronage. She is the scientific editor of the Musica Revelata series, comprising critical editions of music repertoires. Since 2020 she has also headed the nationwide research project titled A Dictionary of Musicians in the Eighteenth-Century Polish-Lithuanian Commonwealth, financed by the Minister of Science and Higher Education as part of the 'National Programme for the Development of Humanities'.

i.bienkowska@uw.edu.pl

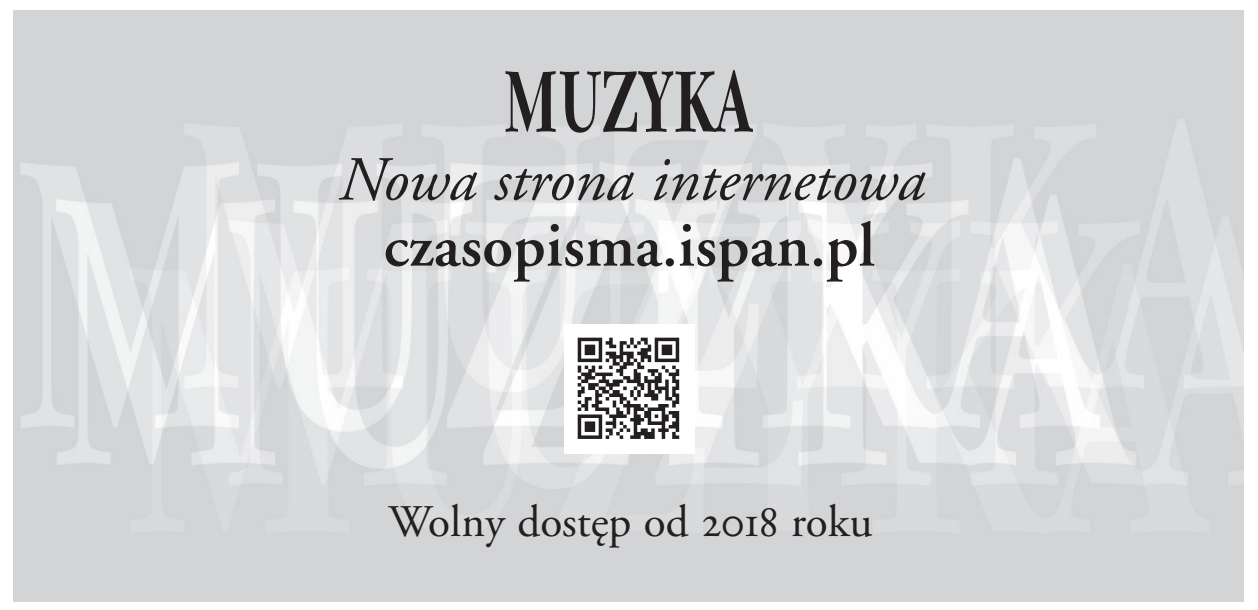

